\title{
異常音による機械の診断 軸受の呼び番号の同定と故障の診断
}

\author{
渡 辺 嘉二郎*・豊 田 成 人* $^{*}$
}

\author{
Diagnosis of Machine from Abnormal Sound \\ - Identification of Standard Numbers of Bearings and Diagnosis of the Failure Modes-
}

\author{
Kajiro WatAnABE* and Naruhito ToyodA*
}

\begin{abstract}
Bearings are the components of rotary machinery, which are easiest to fall into faults. This paper describes how to identify standard numbers of the ball bearings and diagnose their failure modes from scream when they are rotating.

We apply techniques of the neural networks to the identification and the diagnosis. Here we present an architecture of the hierarchically structured multi-layer neural networks. The tasks of identification of the number of bearing and diagnosis of the failure mode are allotted to each hierarchical stages, by which the efficiency of learning and recognition by the network can be improved.

The standard number of a bearing is identified by directly feeding the line power spectrum under the frequency normalized by the revolution frequency to the first stage of the network. The revolution frequency is estimated from the sound of scream. Failure is diagnosed by the networks in the second stage by the information of the standard number of ball bearing, the repetitive frequency of the spectrum and the stationary or nonstationary of the scream.

The ability of associative memory of the neural network can reduce the effect of noise and error in the signal.

The identification and diagnosis of bearings were carried out both by simulation and experiment. We found the hierarchical neural network proposed could effectively identify the standard number and diagnose the faults.
\end{abstract}

Key Words : fault diagnosis, ball bearing, sound information, neural network

\section{1. はじめに}

機械システムにおいて，回転機器の故障はしばしば発 生し被害も大きく, その早期診断が強く望まれている1”。 回転機器で最も多い故障モードは異常振動, 異常音であ り全体の $50 \%$ 近くになり，そのほとんどは軸受の故障で ある2. 本論は回転機器の故障診断の一つとしてボール ベアリングの診断について考える.

軸受の故障診断に関しては，古くから多くの研究が進

$†$ 第 30 回計測自動制御学会学術講演会で発表 $(1991 ・ 7)$

* 法政大学工学部 小金井市梶野町 3-7-2

* Faculty of Engineering, Hosei University, Koganei (Received January 13, 1992)

(Revised July 13, 1992)

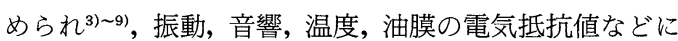
よる診断は実用化されている3. これらのうちボールべ アリングの呼び番号がわかっている場合, 振動, 音響に よる方法は内輪，外輪，玉のいずれが損傷しているかま で診断でき4),5), 呼び番号がわからない場合は, 故障の有 無が判定できる多くの診断装置が開発されてきている.

軸受の使用条件やセンサの取り付け条件, 環境雑音レ ベルなどにより診断の困難さが異なり，人間の判断に依 存せざるを得ないこともある，正常音，故障音をしばし ば聞きそれらの音に馴染んだ人間は，異常音を簡単に聞 き分けるのである8).

本論は，この人間の音響診断能力をニューラルネット ワークで実現することを考える。ニューラルネットワー クは連想記憶性 ${ }^{10)}$ をち，情報欠落のあるデータの識別 
に使われ ${ }^{11)}$,この応用は興味がある.学習済みニューラル ネットワークの知識を一部変更する場合, 変更後の知識 を全体として始めから学習させなければならない ${ }^{11)}$.こ のような問題を解決するために知識を階層化し，それに 対応する階層ニューラルネットワークを構築する方法が 考えられる12),13).

本論は，このような階層ネットワークにより，その第 1 階層でボールベアリングの呼び番号を同定し，第 2 階 層のネットワーク群でそれぞれのボールベアリングの故 障を診断する方法を提案する。このように呼び番号を同 定する手法は従来なかった，呼び番号が同定されると高 精度な故障診断が可能になり，さらに故障ベアリングサ イトの情報も提供できる。

人間の聴覚と同じように，第 1 階層のネットワークに は音のパワースペクトルを直接入力する，つぎに，第 1 階層で同定された呼び番号に対応するネットワークを第 2 階層ネットワーク群から選び，それに悲鳴の繰返し周 波数および悲鳴の定常性/非定常性の情報を入力し故障 を診断する。これらの診断，特に第 1 階層の呼び番号の 同定では, .ニューラルネットワークのパターンマッチン グの能力が効果的に活用できる.

以下，ベアリング音の特徵，階層多段ニューラルネッ トワークの構成を紹介し, ベアリングの同定・診断のシ ミュレーションと実験の結果について述べる。

\section{2. 問題の記述}

Fig. 1 に同定・診断の対象となるボールベアリングの 構造を示す.ボールベアリングは機械軸の回転を案内し， 回転軸にかかる負荷を支える部品である．Fig. 1 に示す ように円形軌道を有する内輪一外輪間を転がる玉の転が り摩擦により動作する。このため振動やそれに伴う音響 が発生しやすい. Fig. 1 に示すボールベアリングについ てつぎの定数, 変数を定義しておく.
$D:$ ピッチ円の直径
$d:$ 玉の直径
$Z$ : 玉の個数
$\alpha:$ 接触角

$f_{r}^{*}$ : 内転回転周波数

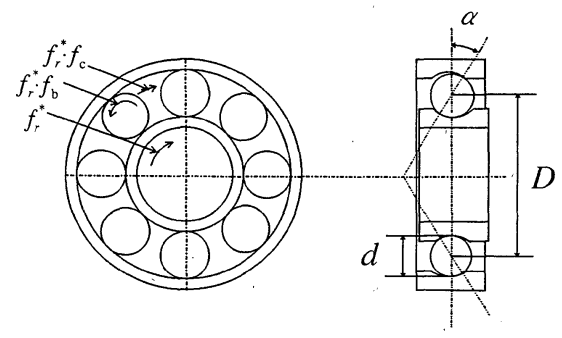

Fig. 1 Ball bearing $f_{b}: f_{r} *$ で正規化した玉の自転周波数

$f_{c}: f_{r}^{*}$ で正規化した玉の公転周波数

$f_{i}:$ 正規化内輪回転周波数 $\{1\}$ と $f_{c}$ との差

$(d, D, Z)$ およびほかのサイズ, 形状に関する定数は形 状寸法, 単に寸法と表現されているが, ここではこれら のうち, $(d, D, Z)$ を形状パラメー夕と呼ぶ。

軸受の運用条件, 軸受音の観測条件および故障につい てつぎの仮定を設ける.

（A 1）内輪のみ回転し外輪は固定されている.

（A 2）外輪に一定のスラスト荷重が加えられている.

（A 3）軸受単体から発生する音を計測する.

（A 4），想定する故障はつぎの 5 種類とする.

$\mathrm{F}_{1}$ : 軌道面が粗くなる.

$\mathrm{F}_{2}:$ 外輪軌道面に一つの傷がつく.

$\mathrm{F}_{3}$ : 内輪軌道面に一つの傷がつく.

$\mathrm{F}_{4}$ : 一つの玉に一つの傷がつく.

$\mathrm{F}_{5}:$ グリースにゴミが混入する。

$\mathrm{N}$ : 正常である.

以上の仮定において, 仮定 (A 1)，(A 2)の条件は軸受 の通常の運用条件である. 仮定 (A 3) は以上の仮定で最 も制約的である。回転機械の近傍ではベアリング音のほ かに様々な音が存在し, 注目するべアリングのみの音を 計測しにくい. しかし, 指向性の高いマイクロホンを注 目するべアリングに近づけたり, 聴音棒を用いれば仮定 (A 3) は満たされる. 従来の診断方法4),5) はほとんどの場 合が加速度計により, 注目するべアリングの振動を検出 する方法でこの仮定の下での方式である. 仮定 (A 4)で 想定される故障はボールベアリングの早期故障のモード である。

以上の仮定のもとで，ボールベアリングの回転音から その呼び番号を同定し故障を診断する。

\section{3. ボールベアリングからの音}

\section{1 呼び番号と音のスペクトル}

いかに優れた製造法によっても, 軸受の軌道輪, 軌道 面, 玉の形状の精度の限界から, 軸受音は発生する.

いま，仮定 (A 1)，(A 2)の条件のもとでボールベアリ ングを用いると内輪回転周波数 $f_{r}$ *で正規化した玉の公 転周波数, 自転周波数, 相対周波数は理論的に

玉の公転周波数 $f_{c}=\frac{1}{2}\left(1-\frac{d}{D} \cdot \cos \alpha\right)$

玉の自転周波数 $f_{b}=\frac{D}{2 d}\left(1-\frac{d^{2}}{D^{2}} \cdot \cos ^{2} \alpha\right)$

相対周波数

$$
f_{i}=1-f_{c}=\frac{1}{2}\left(1+\frac{d}{D} \cdot \cos \alpha\right)
$$
と求められる ${ }^{3), 9)}$. 以下本論では周波数は全て内輪回転周 波数 $f_{r}{ }^{*}$ で正規化する．ボールベアリングから発生する 
音のスペクトルは (1 a )，(1 b)，(1 c) 式の周波数成分とつ ぎの内輪面，外輪面，玉の回転軸方向とその垂直方向の 振動による周波数成分からなる9).

軸心の偏りによる振動周波数 : $1+Z f_{c}$

外輪面軸垂直方向振動周波数： $n Z f_{c}$

内輪面軸垂直方向振動周波数: $n Z f_{i}$

公転により変調を受けた内輪

面軸垂直方向振動周波数： $n Z f_{i} \pm m f_{c}$

回転により変調を受けた内輪

面軸垂直方向振動周波数： $n Z f_{i} \pm m$

玉の自転周波数

$: f_{b}$

玉の軸垂直方向振動周波数 $: 2 n f_{b}$

公転により変調を受けた玉の

軸垂直方向振動周波数 $: 2 n f_{b} \pm m f_{c}$

回転により変調を受けた玉の

軸垂直方向振動周波数 $: 2 n f_{b} \pm m$

ここで, $m=1,2,3, \cdots, n=1,2,3, \cdots$ である.（1 )式,

(2) 式の周波数は, 内輪回転周波数 $f_{r}$ * とボールベアリ ングの形状 $(d, D, Z)$ から定まり，これらの周波数は ボールベアリングの呼び番号に対応する。

\section{2 故障と音のスペクトル}

軌道面や玉に傷のあるボールベアリングでは，音は傷 の上を玉が通過するときに生じる4),5). 軸が定速回転する 場合，故障によって同じ周期で継続する音あるいは間欠 的な音を生じる．継続音の場合，その周期の基本波と高 調波のスペクトルが現れる。この基本波の周波数は繰 返し周波数と呼ばれる。繰返し周波数は故障あるいはそ の個所で異なった值をもち，これから故障原因が診断で きる。

仮定 (A 4) で想定した故障 $F_{1} \sim F_{5}$ および正常 $N$ につ いて音がどのように発生するかを述べる。

【 $F_{1}$ ：軌道面の粗さ】軌道面の微小な凹凸上の玉の通 過による振動。これは面が粗くなった玉の通過による振 動と同じである，振動は玉の自転によるため繰返し周波 数 $f_{b}$ の音が定常的に継続する.

【 $\mathrm{F}_{2}$ : 外輪軌道面の傷】外輪軌道面の 1 力所の傷の上 を $Z$ 個の玉が公転することによる振動。振動は玉の公転 速度により，繰返し周波数 $Z f_{c}$ の音が継続する。

【 $\mathrm{F}_{3}$ : 内輪軌道面の傷】内輪軌道面の 1 力所の傷の上 を $Z$ 個の玉が, 公転速度に対する内輪の相対速度で通過 するときの振動.振動は内輪の相対回転速度によるため, 繰返し周波数 $Z f_{i}$ の音が継続する.

【 $\mathrm{F}_{4}$ : 玉の傷】玉の 1 個の傷がその自転に伴い内輪と 外輪の軌道面に接触するときの振動。玉の傷による振動 のため, $2 f_{b}$ の繰返し周波数の音が継続する. 【F $F_{5}:$ グリースの中への 1 個のゴミの混入】グリース
の中の小さなゴミが玉の自転により内輪と外輪の軌道面 に接触するときの振動. 振動が玉の自転によるため繰返 し周波数は $f_{b}$ で非定常な間欠的な音がする.

【N：正常】（1），(2)式の周波数の微小振動が全て現 れ, 繰返し周波数は現れない.ここで繰返し周波数が現 れないというのは，常時観測できないもので『なし』と し，継続というのは，常時観測できるもので『定常』と する。また間欠的というのは，ある時間間隔では観測さ れ，別の時間間隔では観測できないもので『非定常』と する。

以上より，(1 b)，(2 b)，(2 c)，(2g)式の繰返し周波 数の音が故障時に現れる.

\section{3 呼び番号同定と故障診断のための特徵}

【呼び番号同定のための特徵量】、離散時間 $\Delta t$ でサンプ リングされた音響信号 $x(k \Delta t)$ を $G$ 倍に増幅し FFT ア ルゴリズムにより $\mathrm{dB}$ で表現されたスペクトルを求め る.

内輪回転周波数 $f_{r}$ *では低周波領域内で大きなパワー をもつ.はじめ, 音響信号からこの $f_{r}{ }^{*}$ を推定し, 全ての 周波数を $f_{r} *$ で正規化する. 正規化周波数の 1 から注目 する最大周波数 $f_{\max }$ まで $\Delta f$ ごとのスぺクトルを用い る. 付録から，最大周波数，周波数幅の目安はつぎのと おり。

$$
\begin{aligned}
& f_{\max }=4 \sim 10 \\
& \Delta f<0.3
\end{aligned}
$$

すなわち

$$
\begin{aligned}
& X(l \Delta f)=20 \log _{10}|\mathrm{FFT}\{G x(k \Delta t)\}| \\
& 1 \leqq 1+l \Delta f \leqq f_{\max }, \quad l=1,2, \cdots
\end{aligned}
$$

のスペクトルを特徴として呼び番号を同定する.

【故障診断のための特徵量】離散值音響信号の絶対值を 遮断周波数 $f_{\text {cut }}$ のつぎのローパスフィルタ

$$
\begin{aligned}
& \quad s\{(k+1) \Delta t\}=p \cdot s(k \Delta t)+(1-p) \cdot|G x(k \Delta t)| \\
& p=\exp \left(-2 \pi f_{\text {cut }} \Delta t\right) \\
& \text { で平滑化し, そのスペクトルを求める. } \\
& S(l \Delta f)=\operatorname{FFT}\{s(k \Delta t)\}
\end{aligned}
$$

この処理は包絡線処理と呼ばれる ${ }^{5), 9)} . S(l \Delta f)$ は周期周 波数関数となり，この周期が繰返し周波数である. 以上 の処理を異なる時間帯でのデータに適用し同じスペクト ルが求まるか否で音の定常性 (継続発生), 非定常性 (間欠 発生)を推定する。これら繰返し周波数と音の定常/非定 常性を特徵量としてボールベアリングの故障を診断す る.

(4) 式の呼び番号同定のための特徵量は, 理論的に与 えられる (2)式に比較して，ノイズによりスペクトルの 欠落や別のスペクトルの混入が起こり得る.さらに(2) 式の高調波間の区別は困難であり，計測スペクトルと 
（2）式の周波数の対応は容易ではない.

また故障診断のために求められる繰返し周波数はノイ ズや傷の性質によりバラツキを生じる.

\section{4. 階層型ニューラルネットワークによる診断}

\section{1 階層ニューラルネットワーク}

3.3 節で述べた特徴量よりボールベアリングの呼び番 号を同定し故障を診断する。これらの特徵量には情報の 欠落やノイズの混入があるため，同定・診断に連想記憶 性をもつニューラルネットワークを応用する。

Fig. 2 に提案するニューラルネットワーク構造を示 す。これはパーセプトロン型の 3 層ニューラルネット ワークを階層型に構築したものである．第 1 階層のネッ トワークには ( 4 ) 式で処理したパワースペクトルをその まま入力する．第 1 階層のネットワークの入力ノード番 号は (4a) 式の周波数 $1,1+\Delta f, \cdots, f_{\max }$ に対応し, 各 ニューロンに(4a)式で計算したパワースペクトルを入 力する. (4 b) 式の処理, 第 1 階層のネットワークは人間 の聴覚と類似する構造をもっている ${ }^{14)}$. 第 1 階層の出力 は呼び番号に対応する。

第 2 階層には診断対象とするボールベアリングの種類 の数だけのニューラルネットワークを設ける．各ネット ワークの入力ノードに繰返し周波数と音の定常性/非定 常性の情報を入力し，故障を診断する。これは人間によ る診断と類似している ${ }^{8)}$.

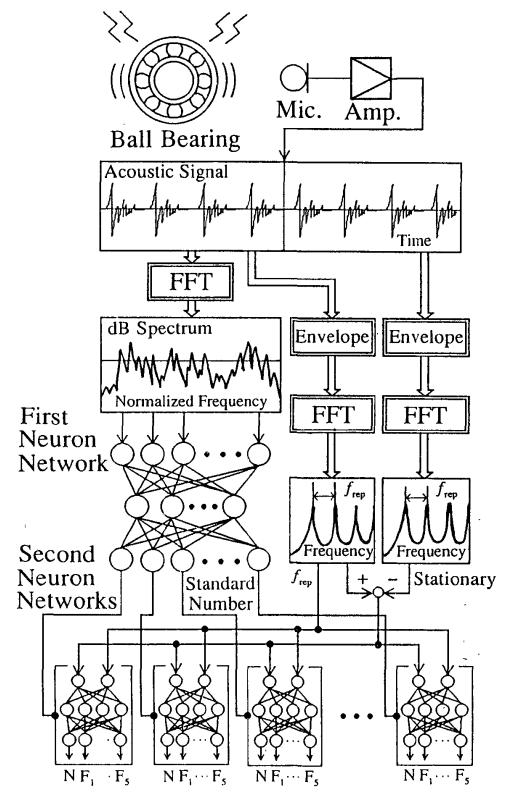

Fig. 2 Diagnostic system

\section{2 学習パターン}

【呼び番号同定のための学習パターン】ボールベアリン グの呼び番号とその形状パラメータ $(d, D, Z)$ には対応 があり，呼び番号がわかるとパラメータがわかる。パラ メー夕を(1)式に代入し，（2) 式の正規化周波数を求め る.（2)式において

$$
n=1, \quad m=1,2,3
$$

とし，つぎのように学習パターンを発生させる。

回転機械の診断では，回転周波数からその 2 倍程度ま でが解析帯域であるので5)，(6)式のもとでは, 回転周波 数からその 6 倍までカバーできる.

$[1+\{(2)$ 式の各周波数 -1$\} / \Delta f]$ のノードに High

$$
\begin{aligned}
& {[1+\{(2) \text { 式の各周波数 }-1\} / \Delta f] \text { の以外の }} \\
& \text { ノードに Low }
\end{aligned}
$$

【故障診断のための学習パターン】

ベアリングの呼び番号が特定されていると, 繰返し周 波数と音の定常性/非定常性から故障原因も唯一に特定 できる. 3.2 節からこの学習パターンは Table 1 のよう になる。

\section{3 階層型ネットワークの特徴}

この故障診断ではベアリングの呼び番号の同定と故障 診断の仕事をしている．これら異種の仕事を，2 層に積 み重なる 3 層パーセプトロンニューラルネットワークで 分担している。これにより，つぎの特徴をもつ.

第 1 階層の呼び番号同定と，第 2 階層の故障診断の ネットワークを一つに構成したネットワークと比較すると， (1) あらかじめパターンマッチング空間を分割している ことから，マッチング空間が狭くなり，学習時間を短 縮し診断精度が向上できる。

(2) 対象とするボールベアリングの種類が増えても，全 体のネットワークを再学習させる必要がない.そのべ アリングの故障診断ネットワークの学習と第 1 階層の ネットワークの再学習のみで済む.

(3) 学習に必要なデー夕は従来の経験に基づくものが多 く，条件によって大きく異なることがある、しかしこ こでは,ネットワークの学習に必要なデー夕はボール ベアリングの呼び番号がわかれば簡単に計算できる。

Table 1 Learning patterns for diagnosis of failure modes

\begin{tabular}{c|c|c}
\hline \hline Failures & $\begin{array}{c}\text { Frequency } \\
\text { Repetition }\end{array}$ & Stationary \\
\hline $\mathrm{N}$ & $\ldots$ & $\ldots \ldots \ldots \ldots . . . .$. \\
$\mathrm{F}_{1}$ & $f_{\mathrm{b}}$ & Stationary \\
$\mathrm{F}_{2}$ & $Z f_{\mathrm{c}}$ & Stationary \\
$\mathrm{F}_{3}$ & $Z f_{i}$ & Stationary \\
$\mathrm{F}_{4}$ & $2 f_{\mathrm{b}}$ & Stationary \\
$\mathrm{F}_{5}$ & $f_{\mathrm{b}}$ & Nonstationary \\
\hline
\end{tabular}




\section{5. 呼び番号同定シミュレーション}

呼び番号の同定のシミュレーションを行う。ここでは スペクトルの欠落に対するニューラルネットワークの連 想記憶性の効果を調べる。

【シミュレーション準備】対象ボールベアリングは 6301〜6305 であり，この形状パラメータを Table 2 に示 す.接触角 $\alpha$ は 0 とした.このパラメー夕から (1), (2) 式，(7)式に基づき学習パターンが作れる。

( 3 ) 式より $\Delta f, f_{\max }$ をづのように選ぶ. $\Delta f=0.04(<0.3), \quad f_{\max }=6$ また（ 6 )式より，(2)式の $n, m$ をつぎのようにした。

$n=1, \quad m=1,2,3$

特徵周波数は 1 から $f_{\max }$ までを採用するので, 周波数の 個数，すなわち入力ノードの個数は

$$
1+\left(f_{\max }-1\right) / \Delta f=1+(6-1) / 0.04=126
$$

となる.中間層のノード数を 4 , 出力層のノード数を 5 (対 象ベアリングの数) とする.

たとえばボールベアリング 6305 では，High を入力す ベきノード番号はつぎの 19 個の番号となる。

$10,19,21,28,35,39,40,48$,

$56,57,59,66,75,84,93,94$,

$102,108,111$

ほかのノードには Lowを入力する。

High $=2$, Low $=-2$ としてバックプロパゲーション 法により，6301〜6305についての学習パターンを教え込 む。

このとき学習は学習係数を 0.9 , 収束係数を 0.1 のも とで, 100 回学習後の出力層の各ノードの出力と教師 データとの 2 乗誤差の和に対して，その和が $10 \%$ になる まで実行した，それに必要な繰返し回数は，2000回で あった。ニューロンの特性を表わすには傾き 2.0 のジグ モイド関数を用いた。入力の範囲はほぼー2〜+2であ り, 出力の範囲は 0 1 である。ネットワークのサイズは $126 \times 5$ のパターンに対し， $126 \times 4 \times 5$ と大きく，少ない 繰返し回数で収束している.

Table 2 Parameters of ball bearings

\begin{tabular}{c|c|c|c}
\hline \hline \multirow{3}{*}{ Number } & \multirow{2}{*}{ Number } & \multicolumn{2}{|c}{ Diameter $[\mathrm{mm}]$} \\
\cline { 3 - 4 } & of Balls & Ball & Pitch \\
& $Z$ & $d$ & $D$ \\
\hline 6301 & 7 & 7.9375 & 24.5 \\
6302 & 7 & 7.9375 & 29.5 \\
6303 & 7 & 8.7313 & 32.0 \\
6304 & 7 & 9.5250 & 36.0 \\
6305 & 7 & 11.1125 & 43.5 \\
\hline
\end{tabular}

Contact angle $\alpha=0 \mathrm{deg}$
【シミュレーション】

初め学習パターンをそのまま入力した，そのときの出 力パターンを Fig. 3 に示す。当然のことながら正しい認 識結果が得られている.

つぎに対象ボールベアリングを 6305 として, スペクト ル欠落の影響を調べた。つぎの(1)〜(5)のケースは重複す る場合を除いて，考えられるほとんどの場合をカバーす る.

また，これらの欠落は現実にはきわめて厳しい条件で あり，通常このように多くの欠落はない.

(1) $n=1, m=1,2$ とし 14 個の線スペクトル(5 個の欠 落 $\times$ )

$10,19,21,28,35,39,40,48$,

$56,57,59,66,75,84,93,94$,

$102,108,1 \times 1$

(2) $n=1, m=1,3$ とし 15 個の線スペクトル 4 個の欠 落 $\times$ )

$10,19,21,28,37,39,40,48$,

$56,57,59,66,75,84,93,94$,

$182,108,111$

(3) $n=1, m=2,3$ とし 10 個の線スペクトル(9 個の欠 落 $\times$ )

$10,19,21,28,35,39,40,48$,

$56,57,59,66,75,84,93,94$,

$102,108,1 \times 1$

(4) $n=1, m=1$ としさらに 3 個を欠落させ, 残り 7 個 の線スペクトル $(12$ 個の欠落 $\times)$

$10,19,21,28,35,39,40,48$,

$56,57,59,66,75,84,93,94$,

$1 风 2,108,1 \times 1$

(5) $n=1, m=2$ とし 4 個の線スペクトル(15 個の欠 落 $\times$ )

$10,19,21,28,35,39,40,48$,

$56,57,59,66,75,84,98,94$,

$1 \% 2,118,1 \times 1$

結果を Fig. 4 に示す.情報欠落により出力レベルは少

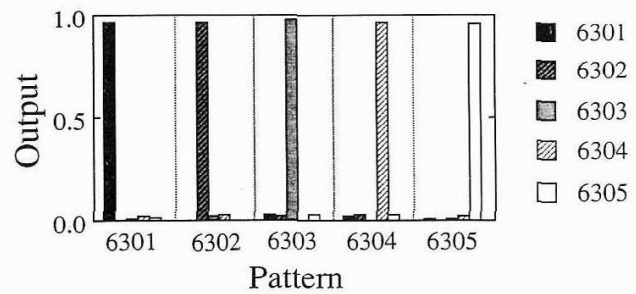

Fig. 3 Identification of standard numbers by using the learning patterns themselves 


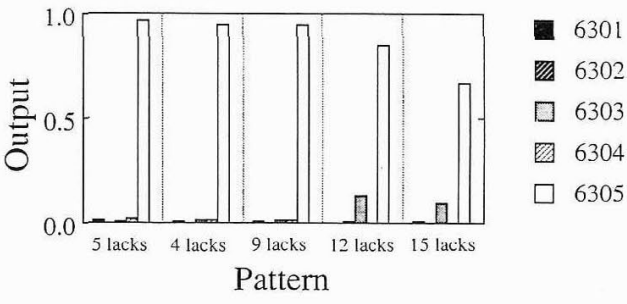

Fig. 4 Identification of standard numbers by using patterns with lacking spectra

し下がるが，全ての場合で呼び番号は正しく同定されて おり，ニューラルネットワークの連想記憶性が効果的に 作用している.

\section{6. 呼び番号同定と故障診断の実験}

\section{1 実験条件}

【対象ボールベアリングと計測条件】対象ボールベアリ ングは 6301 LLB〜 6305 LLB(NTN 製造)である. 6305 LLBについて故障を診断した。

単体のボールベアリングに $8 \mathrm{~kg}$ のスラスト荷重を加 え, $f_{r}{ }^{*}=30 \mathrm{rps}[\mathrm{Hz}]$ で回転させ, ベアリングから $0.1 \mathrm{~m}$ 離した場所で音を計測した。

【呼び番号同定のためのパラメータ設定】データの A/D 変換サンプリング間隔 $\Delta t=100 \mu \mathrm{S}$, FFT を施すデータ 数は $N=8192$ とした. 音響信号には遮断周波数 $5 \mathrm{kHz}$ の ローパスフィルタを施している。

$$
\begin{aligned}
& \Delta f=1 /\left(N \cdot \Delta t \cdot f_{r}{ }^{*}\right)=0.0407 \\
& 1+\left(f_{\max }-1\right) / \Delta f=1+(6.1269-1) / 0.0407=126
\end{aligned}
$$

で，適正なサンプル間隔，データ数が選ばれている.

第 1 階層の呼び番号同定のニューラルネットワークは つぎの構造をもつ.

入力層のノード数 $=126$, 中間層 $=4$, 出力層 $=5$ 学習条件はシミュレーションの場合と同じである. 【設定故障と診断のためのパラメータ】ボールベアリン グに仮定 (A 4) で想定した故障を作った。

包絡線処理のためのローパスフィル夕遮断周波数は, $f_{\text {cut }}=150 \mathrm{~Hz}$ とし，(5) 式より繰返し周波数を求めた。

ボールベアリング 6301 LLB〜6305 LLB の故障診断 のために第 2 階層 5 個のネットワークを設けた。各ネッ トワークのノード数はつぎのようにした。

入力層のノード数 $=2$, 中間層 $=4$, 出力層 $=6$

学習パターンは Table 1 に基づく. 表中の $f_{b}, Z f_{c}, Z f_{i}$, $2 f_{b}$ は各ボールベアリングの構造パラメータから求め た. 音の定常性/非定常性については, 定常 $=2$, 非定常 $=-2$, なし $=-2$ として入力の学習パターンを発生させ, それを学習させ
た. 学習係数, 収束係数, 収束条件は呼び番号同定ネッ トワーク学習の場合と同様にし，100 回学習後の出力層 の各ノードの出力と教師データとの 2 乗誤差の和に対し

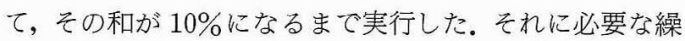
返し回数は 6000 回であった。

ネットワークのサイズは $2 \times 6$ のパターンに対し， $2 \times$ $4 \times 6$ と小さく, 繰返し，回数が多くなっている.

\section{2 実験結果}

【内輪回転周波数の推定】 Fig. 5 に内輪に傷がある $\left(\mathrm{F}_{3}\right)$ 場合のボールベアリング音の $0 \sim 40 \mathrm{~Hz}$ の間のパ ワースペクトルを示す. $0 \mathrm{~Hz}$ から観測して初めてピーク が現れる周波数が $f_{r}{ }^{*}$ である. Fig. 5 から $f_{r}{ }^{*}$ は 30.5 $\mathrm{Hz}$ と推定できる。ボールベアリングに傷がない場合，ほ かの傷がついている場合もほぼ同じ周波数が読み取れ る.

【呼び番号の同定】Fig.6に正常なボールベアリング (6305 LLB) の音の時系列波形とパワースペクトルを示 す. Fig. 7 には同じ呼び番号のボールベアリングに外輪 軌道面に傷 $\left(\mathrm{F}_{2}\right)$ がある場合, Fig. 8 にはグリースにゴミ が混入 $\left(\mathrm{F}_{5}\right)$ した場合の波形を示す。

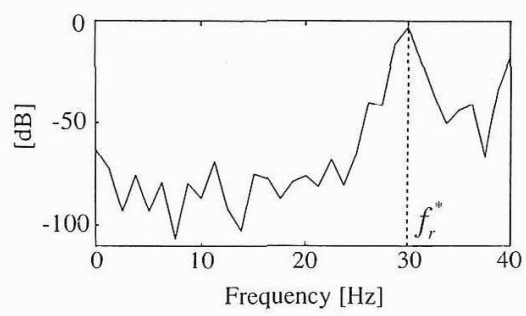

Fig. 5 Estimation of rotating frequency
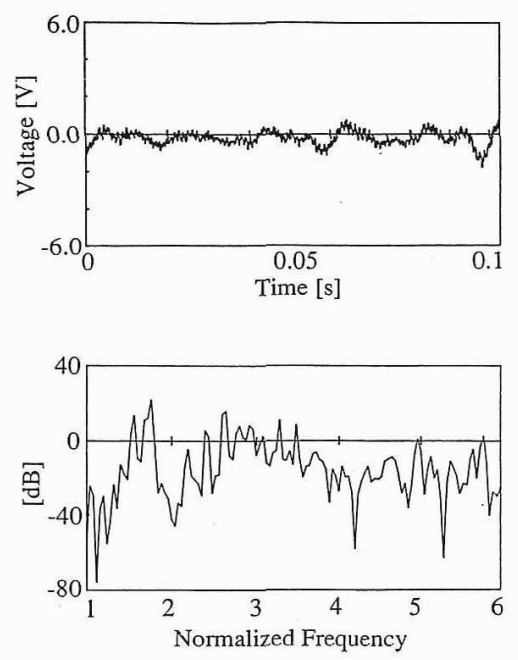

Fig. 6 Normal 

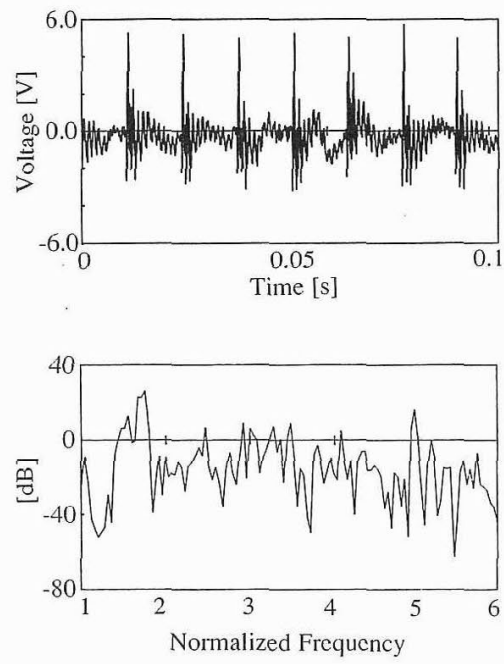

Fig. 7 Defect on the outer race
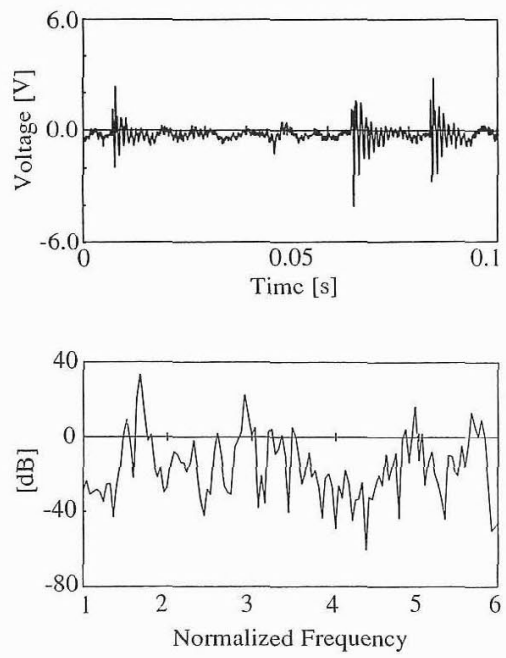

Fig. 8 Dust in the grease

Fig. 6 の正常ボールベアリング音は，故障音に比べて 音のレベルが低い.Fig. 7 では周期音が定常的に発生し ているのに対して，Fig. 8 では音が非定常的である.

6305 LLB について, 正常 $(\mathrm{N})$ の場合, 故障 $\left(F_{1}, F_{2}, F_{3}\right.$, $\left.\mathrm{F}_{4}, \mathrm{~F}_{5}\right)$ の場合のパワースペクトルをシミュレーション で用いたネットワークの第1階層に直接入力しバアリン ダ呼び番号を同定する。ネットワークからの出力を Fig. 9 に示す。いずれの場合も呼び番号 6305 を正しく同定し ている。

【故障診断】同定された呼び番号より第 2 階層の中から 対応するネットワークを選択する。6305の場合でこの

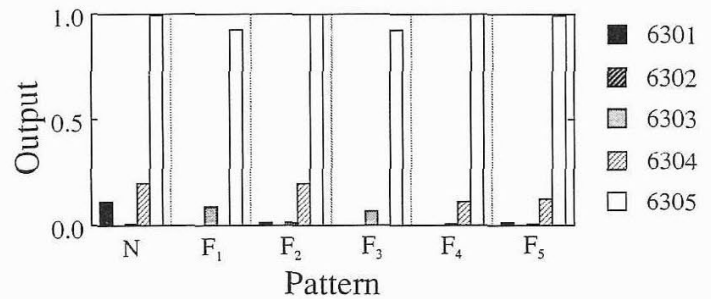

Fig. 9 Identification of standard number by screaming of faulty ball bearing

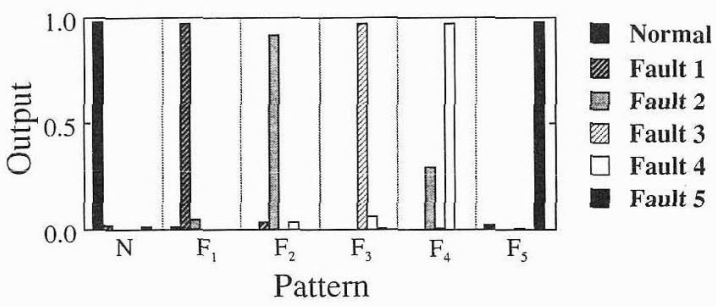

Fig. 10 Diagnosis of failure modes by screaming of faulty ball bearing

ネットワークに繰返し周波数の值と定常/非定常性の情 報を入ノする。繰返し周波数のばらつきは $5 \%$ 程度ある。 正常 $(\mathrm{N})$ ，故障 $\left(\mathrm{F}_{1}, \mathrm{~F}_{2}, \mathrm{~F}_{3}, \mathrm{~F}_{4}, \mathrm{~F}_{5}\right)$ のデー夕を入力した場 合のネットワーク出力を Fig. 10 に示す. 全ての故障が 正しく診断されている。

\section{7.むすび}

ボールベアリング音より，その呼び番号を同定し故障 を診断する方法について述べた。階層構造をもつニュー ラルネットワークを導入し，上の二つの仕事を各階層に 分担させた。この方法は以下の特徵をもつ。

(1) 周波数による回転機械の診断は，回転周波数で正規 化して解析する。この回転周波数を知るためには，マ イクロホンのほかに回転計などのセンサが必要となる が,ここでは回転音から内輪回転数周波数が推定でき， これで全ての周波数が正規化できる.

(2) 階層型ニューラルネットワークに新たな知識を加え たい場合，一部のネットワークのみを再学習させれぱ よい.

(3) 学習データはポールベアリングの設計データから全 て発生できる。

(4) 音の情報(スペクトル)のかなりの众落があっても， 正しく呼び番号が同定できる。

(5) 検出される繰返し周波数にばらつきがあっても, 正 しく故障が䛦断できる。 


\section{参 考 文 献}

1) 安全工学協会 : 安全工学講座 4 故障, 海文堂 (1982)

2）池田三郎：故障診断マニュアル；感覚を働かせた故障診 断のテクニック，電気書院 (1980)

3）五十嵐昭男：転がり軸受の振動おうび音響, 潤滑, 32-5, 317/322(1987)

4）五十嵐昭男：欠陥をもつ転がり軸受の振動・音響に関する 研究(第 1 報 1 個の傷がある玉軸受の振動), 日本機械学会 論文集(C)，47-422，1327/1336(1981)

5）滝瀬忠：ボールベアリングを組み込んだ小型機器の回転 音による診断法，日本音響学会誌，44-6，419/424(1988)

6）有本健夫：転がり軸受, 潤滑, 26-4, 247/251(1981)

7) 吉岡武雄：転がり軸受の新しい異常検知法について, 潤 滑, 26-2，85/90(1981)

8）城戸健一：信号処理による機械系の診断・監視，電子情報 通信学会誌, 72-1，107/109(1989)

9）豊田利夫：図解・設備診断技術シリーズ 1 ; 回転機器診断 の進め方，日本プラントメンテナンス協会 (1991)

10）中野馨：ニューロコンピュータの基礎，コロナ社(1990)

11) McClelland and D.E. Rumelhart, eds : Parallel Distributed Processing : Explorations in the Microstructure of Cognition, Vols. 1, 2, 3, MIT (1986)

12) K. Watanabe et al. : Incipient Fault Diagnosis of Chemical Process via Artificial Neural Networks, AIChE J. 35-11, 1803/1812 (1989)

13) K. Watanabe and S. Hirota : Incipient Diagnosis of Multiple Faults in Chemical Process via Hierarchical Neural Network, IECON'91, 1500/1505(1991)

14）難波精一郎：聴賞ハンドブック，ナカニシヤ出版(1984)

\section{《付録 1 最大周波数 $f_{\max }$ と周波数幅 $\Delta f 》$}

通常のボールベアリングで玉の個数は $Z=5 \sim 14$,玉 の直径とピッチ円の直径の比 $d / D=0.25$, 接触角 $\alpha$ は小 さい.一つの目安を得るため $n=1, m=1$ とする。

はじめ $f_{\max }$ の目安となる範囲を求める. 最大の周波数 は $(2 \mathrm{e})$ 式より与えられる。 $Z=5$ の場合,

$$
f_{\max }=Z f_{i}+m=Z \cdot \frac{1}{2}\left(1+\frac{d}{D} \cos \alpha\right)+m=4.12
$$

$Z=14$ の場合, $f_{\max }=9.75$ となる. したがって, $f_{\max }$ の 範囲は

$$
f_{\text {max }}=4 \sim 10
$$

が目安になる。

つぎに $\Delta f$ の目安を求める。（2）式から最も隣接する
周波数は $(2 \mathrm{c})$ と $(2 \mathrm{~d})$ 式，あるいは $(2 \mathrm{~g})$ と $(2 \mathrm{~h})$ 式であ る.いずれの場合も周波数幅は $f_{c}$ で与えられる。した がって，通常のボールベアリングで，最小の $\Delta f$ は

$$
\Delta f<f_{c}=\frac{1}{2}\left(1-\frac{d}{D} \cos \alpha\right)=0.375
$$

である。したがって $\Delta f$ の目安はつぎのようになる。

$$
\Delta f<0.3
$$

\section{《付録 2 ジグモイド関数と結合荷重の修正量》}

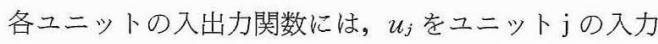
值の総和とすると,つぎの傾き $T$ のジグモイド関数を用 いた。

$$
f\left(u_{j}\right)=\frac{1}{1+\exp \left(u_{j} / T\right)}
$$

学習にはバックプロパゲーション法を用い，このと

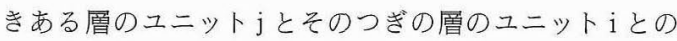
結合荷重の修正量 $\Delta W_{j i}(t)$ 屿以下の式によって求めた。

$$
\begin{aligned}
& \Delta W_{j i}(t)=-\eta \cdot \delta_{j} \cdot O_{i}+\alpha \cdot \Delta W_{j i}(t-1) \\
& \delta_{j}=\left(O_{j}-T_{j}\right) \cdot f^{\prime}\left(u_{j}\right)
\end{aligned}
$$

ここで, $t$ : 学習回数, $\eta$ : 収束係数, $O_{j}:$ ユニット $\mathrm{j} の$ 出力 $\left(O_{j}=f\left(u_{j}\right)\right), T_{j}:$ ユニット $\mathrm{j}$ の教師データ, $\alpha$ : 学 習係数

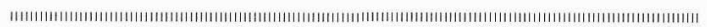

\section{[著 者 紹 介]}

\section{渡 辺 嘉二郎 (正会員)}

(本号 p. 17 参照)

\section{豊 田 成 人 (学生会員)}

現在, 法政大学大学院工学研究科システ ム工学専攻修士課程在学中. ニューラル ネットワークを用いた故障診断の研究に従 事.

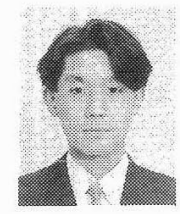

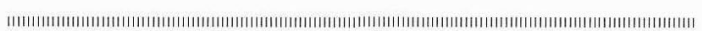

